\title{
Pandeminin Kamusal Mekan Kullanımlarına Etkisi ve Güncel Mekansal Oluşumlar
}

\author{
Gizem Güvlü ${ }^{*}$, Halime Nur Y1lmaz ${ }^{2}$ \\ ${ }^{1 *}$ Süleyman Demirel Üniversitesi, Fen Bilimleri Enstitüsü, Mimarlık Fakültesi, 100/2000 YÖK Doktora Bursiyeri, Isparta / Türkiye, ORCID ID: 0000-0002-2882-1818, \\ d1940147025@ogr.sdu.edu.tr \\ 2Süleyman Demirel Üniversitesi, Fen Bilimleri Enstitüsü, Mimarlık Fakültesi, Isparta / Türkiye, ORCID ID: 0000-0002-8404-9957, yl1930129014@ogr.sdu.edu.tr
}

(İlk Geliş Tarihi 7 Haziran 2021 ve Kabul Tarihi 15 Ağustos 2021)

(DOI: 10.31590 /ejosat.949168)

ATIF/REFERENCE: Güvlü, G. \& Yılmaz, H. N. (2021). Pandeminin Kamusal Mekan Kullanımlarına Etkisi ve Güncel Mekansal Oluşumlar. Avrupa Bilim ve Teknoloji Dergisi, (27), 135-144.

\section{$\ddot{O} z$}

Günümüze kadar 121.382.067'den fazla kişinin hastalandığı 2.683.209'dan fazla kişinin ise yaşamını kaybettiği Covid-19 salgını mekânların geçmişteki haliyle kullanılmasını zorlaştırmış, farklı ihtiyaçların ve kullanım alışkanlıklarının ortaya çıkmasını ve mekânsal düzenlemelerde birtakım değişiklikler yapılmasını gerekli kılmıştır. Bu değişimin doğru şekilde gerçekleştirilmesi için ise farklılaşan mekânsal düzenlemelerin ayrıntılı şekilde ele alınması gereklidir. Araştırmada mekân kullanımlarındaki değişikliklere ve pandemi sürecine uygun olarak geliştirilen tasarım önerilerine değinilmiş, kamusal kullanıma açık alanlardaki mekânsal farklılaşmalar gösterilmiştir. Çalışmada pandemi sürecini yaşayan bireylerin mekânsal kullanımlarının, salgının bitişi ile anlamlı bir ilişkisinin bulunup bulunmadığı ve mekân kullanım şekillerinin bir davranış kalıbına dönüşüp dönüşmediğini anlamak için iki farklı senaryo ile yerel halktan oluşan bireylere sorular sorulmuştur. 166 kişiye uygulanan anket çalışması ile değişen mekân kullanımları belirlenerek yerel halkın mekânsal ihtiyaçlarının ne kadar değiştiği ve şu an var olan kullanım şeklinin hangi durumlarda devam ettirileceğinin sorgulaması gerçekleştirilmiştir. Araştırma sonucunda yapılan anket çalışmasından elde edilen verilerin değerlendirmesi yapılmış, kamusal mekan kullanımlarındaki değişimin pandemi sonrası süreçte de kalıcılığının devam edeceği yargısına ulaşılmıştır.

Anahtar Kelimeler: Kamusal Mekan, Mekansal Değişim, Fiziksel Mesafe, Pandemi

\section{The Impact of the Pandemic on Public Space Uses and Current Spatial Formations}

\begin{abstract}
The Covid-19 epidemic, in which more than 121,382,067 people became ill and more than 2,683,209 people lost their lives to date, has made it difficult to use the spaces as they were in the past, necessitating the emergence of different needs and usage habits and some changes in spatial arrangements. In order for this change to be realized correctly, it is necessary to deal with the differing spatial arrangements in detail. In the research, the changes in the use of space and the design proposals developed in accordance with the pandemic process were mentioned, and the spatial differentiations in the areas open to public use were shown. In the study, questions were asked to individuals consisting of local people in two different scenarios in order to understand whether the spatial use of individuals experiencing the pandemic process has a meaningful relationship with the end of the epidemic and whether the use of space has turned into a behavioral pattern. With the questionnaire study applied to 166 people, the changing use of space was determined and the question of how much the spatial needs of the local people have changed and in which situations the current use will be continued. As a result of the research, the data obtained from the survey study was evaluated, and it was concluded that the change in the use of public spaces will continue to be permanent in the post-pandemic period.
\end{abstract}

Keywords: Public Space, Spatial Change, Physical Distance, Pandemic

* Sorumlu Yazar: d1940147025@,ogr.sdu.edu.tr 


\section{Giriş}

Çin'in Wuhan kentinde 2019'un son aylarında ortaya çıkan Covid-19 salgını hızlı bir şekilde yayılarak küresel bir salgın halini almış ve pandemi krizine yakalanan dünya, salgınla mücadelede çözüm arayışlarına girmiştir. Sürecin hızla ilerlemesinde bireylerin paylaşım içerisinde olması ve geçmişte yaşanan salgınlardan farklı olarak pandemiye yakalananların çoğunun teşhis edilmeden topluma karışabiliyor olması virüsün yayılımını hızlandırmıştır. Tarihsel süreçte yaşanan salgınlardan edinilen tecrübeler pandemi ile mücadelede sadece tıbbi çözüm arayışlarının yeterli olmayacağını, birtakım kamusal değişikliklerin de gerekli olduğunu göstermiştir. Yapılaşmış çevreyi yeniden şekillendiren salgının etkisinin ve yayılımının azaltılmasında mimarlık ve mühendislik gibi disiplinlerin kritik bir öneme sahip olduğunun farkına varılmıştır. (Tekeli İ, 2000) Sosyal ve mekansal etkileri beraberinde getiren pandemi hepimizin hayatını etkilemiş, bu zamana dek pek de aşina olmadığımız birçok kavramı (sosyal mesafe, karantina vb.) gündelik yaşantımızın tam merkezine yerleşmiştir. İhtiyaç duyulan yeni bir fiziksel biçimlenme mimaride de bazı değişikliklere yol açmıştır. Yaşanılan salgın dolayısıyla değişen davranış kalıpları var olan kurulu düzenin uygulanabilirliğinin sorgulanmasına sebep olurken, yaşantılarımızın kapsayıcısı olan mekanların yeniden düzenlenmesini gerektirmektedir.

$\mathrm{Bu}$ anlamda tarihsel süreçte yaşanan salgın hastalıkların farklı mekânsal oluşumlara yol açtığı göz önünde bulundurulduğunda yaşadığımız dönemde görülen pandeminin de mekânsal birtakım etkilerinin olmaması olanaksızdır. Bu nedenle çalışmada yola çıkılan hipotez; pandeminin kamusal mekanlara getirdiği değişimin pandemi sonrası süreçte de kalıcılığının devam edeceği üzerine kurulmuştır. Araştırma boyunca mekânın algılanabilen varoluşsal hali ile anlamsal açıdan yeniden tanımlamasına, pandeminin mekan kavramına getirdiği oluşumların neler olduğuna ve bu mekânsal değişimin hangi düzeyde kalıcı olacağı ve sosyal hayatın bir parçası haline gelen 'fiziksel mesafe, sosyal izolasyon' gibi kavramların pandemi sonrası dönemde de süreklilik kazanıp kazanmayacağı sorularının anket yöntemi kullanılarak yanıt aranmıştır.

Çalışmada pandemi öncesi ve pandemi sonrası mekân kullanımları belirlenen başlıklar altında incelenmiştir. $\mathrm{Bu}$ inceleme sırasında öncelikli olarak literatür taraması yapılıp pandemi süreci, mekân kavramı ve algısına değinilerek kuramsal çerçeve oluşturulmuş daha sonra yöntem iki aşamalı olarak yürütülmüştür. Birinci aşamada değişen mekan alışkanlıkları araştırılmış ve şekilsel olarak ifade edilmiştir. İkinci aşamada ise değişen alışkanlıklarla ilişkili olarak anket çalışması ile yerel halktan seçilen kullanıcıların görüşleri belirlenmiştir. Anket sonuçları SPSS programında gerekli analizlerden geçirilerek değerlendirilmiştir.

\subsection{Mekan Kavramı}

Pandemi hiç şüphesiz en çok yaşadığımız mekanları etkilemiş, yaşantılarımızı devam ettirebilmek için ise bizleri öncelikli olarak bu mekanları düzenlemeye itmiştir. Kavramsal açıdan mekan kavramı için literatürde birçok tanımlama bulunmaktadır. Asar (2013)'ın da belirttiği gibi mekan mimari bir yapının en önemli kurucu öğelerinden biridir. Kavramsal olarak ele alındığında akla ilk gelen şekilde gerçekte, içinde yaşayarak hareket ettiğimiz bazı yapısal elemanlarla çevrelenen bir boşluktur. Ancak mekan sabit, rijit ve tek bir tanımlamaya sığabilecek maddeden bağımsız bir kavram değildir. Aksine dinamik, devingen ve birçok tanımlamaya açık göreceli bir kavramdır. Birden çok nesnenin arasındaki ilişki ve algılanabilir olması bir yerin mekân olarak tanımlanabilmesi için yeterli görülmektedir. (Asar, 2013) Yaşanılan süreçte değişen yaşam şartlarına adapte olabilmek için eskisinden daha iyi düzenlenmiş mekanlara ihtiyaç duyulurken, fenomenolojik açından mekân, yaşamın temel ögesi olarak görülmüş ve bu yüzden bir nicelik olarak değerlendirilmiştir. Mekân kavram, insan eylem ve etkinlikleri için gerekli bir donanım ve bir hammaddedir. Her varlık da var olarak bu hammaddeyi kullanır, işgal eder ve onu tüketir. $\mathrm{Bu}$ düşünceden yola çıkarak Bilgin (1990) ve Solak (2017) mekanı varoluşun ve eylemin hammaddesi olarak kabul etmektedirler. (Bilgin, 1990; Solak, 2017)

Varlığın var oluşunun göstergesi olan mekanlardan insan için üretilenlerin belirli şartları taşıması gerekmektedir. Birçok açıdan yönetmelik ve şartnamelerle kurallara tabi tutulan mekansal gereklilikler matematiksel birtakım öğelere dönüşür. Nicel olarak ifade edilen mekânsal düzenleme girdileri uygulamada yaşantılara, kültürel etkilere ve algısal boyutlara bağlı olarak farklılık gösterebilmektedir. Bahsedilen açıdan mekan insan yaşantısını her yönüyle sararak zaman kavramı ile birlikte sürekli şekillenmektedir. Yaşanılan dönemin getirdiği olanaklarla gelişim gösteren ve gün geçtikçe hızla tüketilen mekan, sahip olduğu kullanım yoğunluğu ile doğru orantılı olarak değişim gösterir.

Geçmişten günümüze mekânsal tüketimin belirgin bir şekilde okunduğu kamusal mekanlar, insanların sürekli etkileşim halinde olduğu ve yaşanan bu etkileşimle birlikte değişimin en net gözlemlendiği alanlardır. Çalışma dahilinde incelenecek olan kamusal alanlar, orada yaşayan kentlilerin tümünün erişim sağladığı, herkesin kullanımına açık olan ortak bir sosyal hayatın oluşumuna zemin hazırlayarak bir kenti kent yapan ve yaşatan en önemli kentsel mekanlar olarak tanımlanmaktadır. (Erdönmez \& Çelik, 2016)Tüm bu mekânsal tanımlamaların hepsi de mekanın yaşantıya yani algılamaya bağlı olarak değişkenlik gösterebildiğini ortaya koymaktadır.

\subsection{Mekanda Algı}

Mekân, sayısız farklı biçimde algılanabilmektedir. $\mathrm{Bu}$ algılamada kişi deneyim ve becerileri yoluyla gözlem yapma, algılama, ayrıntıyı fark etme ve hayal gücünü kullanma gibi niteliklerden faydalanır. Kişide oluşan mekânsal algı bahsedilen nitelikler ile bilişsel olarak bir değerlendirmeden geçirildikten sonra anlamlandırılmaktadır. Bu nedenle mekân tek başına bir anlam ifade etmemektedir ve kullanıcı ile etkileşimi sonucunda mekân algısı oluşmaktadır. Bulunulan mekân ve çevre ile bağlantılı olarak etkileşim; sosyo-kültürel fiziksel ve algısal değişkenlere göre çeşitlenebilmektedir. Oluşan algıyla birlikte kullanıcılar mekânın biçimlenişine göre hareket etmekte, mekânın biçimlenişi de kullanıcıların geri dönütlerine göre yeniden şekillenebilmektedir. (Asar, 2013)

Lefebvre (1991)'nin üçlü diyalektiğine göre ise mekân toplumsal olarak üretilir. Yaşanan, algılanan ve tasarlanan mekân, mekân üretiminde birbirinden ayrılmaz üç kurucu parçadır. Ancak bilimsel pratikler içinde "mekân"'ın algılanan, tasarlanan ve yaşanan boyutları birbirlerinden ayrılmıştır - bunlar sırasıyla, fiziksel, zihinsel(algısal) ve toplumsal mekânlara karşılık gelmektedir. (Avar, 2009; Lefebvre, 1991) Mekân kavramını 
bütün duyu organlarımızla algılayarak oluşumları belleğimizde mevcut olan durumlarla karşılaştırırız. (Altan, 1993) Bu karşılaştırmalarda kişilerin kültür ve deneyimlerini de içeren psiko-sosyal durumu, mekân içinde geçirilen zaman, mekânın 1şık, 1sı, konum vb. gibi fiziksel faktörleri mekânın algılanmasını doğrudan etkilemektedir. Algısal açıdan bu çeşitlenmeyle birlikte mekân, öznesi olan insanla var olarak ve onunla anlamlanmaya devam eder. İnsan ile iletişime geçtiği her an yeniden üretilir. $\mathrm{Bu}$ devingen süreçte mekânsal algı; kişiden kişiye değişen farklı duyguları, istekleri, tercih ve mekanı yeterli bulup bulmadıklarını anlatan bir yansımadır. (Duman, 2018)

Bahsedilenler göz önüne alındığında mekânın algılanması, hem duyumsal hem de zihinsel bir süreç sonrasında gerçekleştiği görülmektedir. (Solak, 2017) Bütün bu etkiler günümüzde düşünüldüğü zaman psiko-sosyal durumun mekân algısında yükselen bir değere sahip olabileceği, yaşanılan süreç dolayısıyla mekan algısının değişebileceği göz önünde bulundurulmalıdır.

\section{Materyal ve Metot}

Çalışmada materyal olarak yerel halktan oluşan ve farklı yaş gruplarında dağılım gösteren anketörlerden alınan cevaplar ile pandemi sürecinde kamusal mekanlarda meydana gelen mekânsal değişikler ele alınmıştır. Araştırmada pandemi sürecini yaşayan bireylerin mekânsal kullanımlarının ve kazandıkları yeni davranış kalıplarının kalıcılığını sorgulayabilmek için anket yönteminden yararlanılmış; iki farklı senaryo oluşturularak yerel halktan oluşan 166 bireye sorular yöneltilmiştir.

Etik kurul izni ile 2021 Mart ve Nisan aylarında yapılmış olan anket çalışmasına katılımlar çevrimiçi olarak gerçekleştirilmiştir. Katılımcilar arasından 92 tanesi 15-24, 57 tanesi 24-44, 16 tanesi 45-65 ve 1 tanesi 65 yaş ve üzeri grupta yer almaktadır. Eğitim seviyeleri ve iş durumları bakımından ise 67 kişinin öğrenci, 32 kişinin çalışmıyor ve 69 kişinin ise aktif olarak çalışıyor olduğu görülmüştür.

\begin{tabular}{|c|l|}
\hline \multirow{2}{*}{$\begin{array}{c}\text { PENARYO } \\
\mathbf{1}\end{array}$} & $\begin{array}{l}\text { Pandeminin küresel ölçekte önüne geçildiği ve } \\
\text { belirli bir süredir dünyada tek bir kişide bile } \\
\text { vakaya rastlanılmadığının bilindiği bir dünya }\end{array}$ \\
\hline \multirow{2}{\text{SENARYO}}{} & $\begin{array}{l}\text { Pandeminin önüne geçilemediği, tüm dünyaya } \\
\text { hıla yayılmaya devam ettiği ve bundan }\end{array}$ \\
$\mathbf{2}$ & $\begin{array}{l}\text { sonraki yaşam sürecinde asla bitmeyecek } \\
\text { salgın hastalıklar silsilesinin içerisinde } \\
\text { olunduğunun bilindiği bir dünya }\end{array}$ \\
\hline
\end{tabular}

Çizelge 1. Ankette katılımcılara sunulan iki farklı senaryo

2 farklı senaryota tabloda yer verilen açıklamalar göz önünnde bulundurularak katılımcıların soruları cevaplandırmaları istenmiştir. Bu sorular ile aranan cevap, pandemi sonrası süreçte hastalık tamamen sonra erse bile değişen davranış kalıplarının kalıcılığının ne derece devamlı olacağının ölçülmesi ya da tam tersine sürekli yeniden karşımıza çıkabilecek salgın hastalıklar silsilesi içerisinde kural tanımayan bir topluluk ile mi karşılaşacağı sorusuna yanıt aranmıştır.

\section{Araştırma Sonuçları ve Tartışma \\ 3.1. Kamusal Mekan Kullanımlarındaki Değișimler}

\section{Yeme/ İçme Mekanları}

Pandemiyle birlikte hayatımızda önemli bir yer edinen fiziksel mesafe kavramı; restoran, lokanta gibi gıda sektöründe hizmet veren mekanlarda da önemli bir faktör haline gelmiştir.
(Şekil 1) Virüs iletimini engelleyen en etkili öge olan maskeden bu mekanlarda yararlanamadığımız için bulaş riskini en aza indirgemek ancak sosyal mesafe kurallarına uymak ile mümkün görülmüştür ve bu yüzden yeme/içme mekanlarında kullanıcılar arasında yeterli mekânsal mesafe bırakılmaya çalışılmıştır. (Şekil 2) $\mathrm{Bu}$ anlamda oluşan mekânsal değişim sadece pandemi sürecinde değil, pandemi sonrası dönemde de mekanların tahmin edemediğimiz durumlarla karşılaşabileceğimiz öngörüsünü ortaya çıkarmıştır. Pandemi sonrası dönemde yeni tasarlanacak restoran/ kafe tarzı mekanlar için gel al servisin ilerleyen süreçte daha fazla rağbet görebileceğini düşünerek mekanların dişarıyla olan bağlantısı arttırılıp müşterilerin mekanın içerisine dahil olmadan siparişlerini alabilecekleri bekleme alanları oluşturulmalı, kullanıcılarının birbirlerinden izole bir şekilde mekânı deneyimleyebileceği ayrı oturma alanları düzenlenerek olası bulaş riskini en aza indirgeyecek uygun mekânsal çözümlemeler getirilmelidir. (fiziksel ölçüler, m2'ye düşen insan sayısı gibi) (Şekil 3)

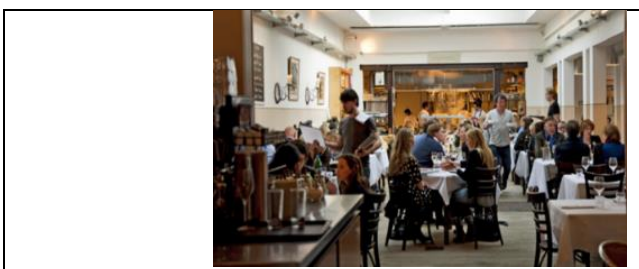

Şekil 1. Pandemi öncesi restoran mekan kullanımı (url-1)

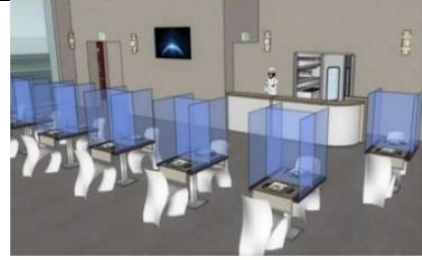

Şekil 2. Pandemi sürecinde restoran mekan kullanımının değişimi(url-2)

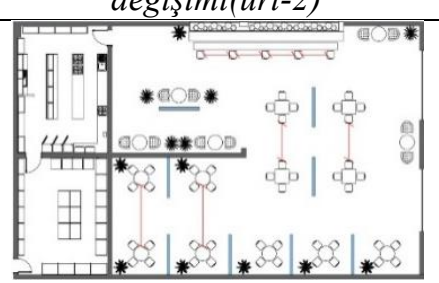

Şekil 3. Pandemi sürecinde restoran yerleşim planı incelemesi

\section{Spor Yapıları}

Pandemi öncesinde belli bir kullanıc potansiyeline sahip olan spor yapıları pandemiyle birlikte sosyal mesafe ve hijyen standartlarını yeteri kadar sağlayamayacağı (Şekil 4) endişesiyle öncelikli olarak kapatılmış sonrasında spor salonu gibi özel teşebbüse ait az sayıda kişinin toplanmasına sebep olan mekanlar ise çeşitli kısıtlamalar dahilinde düzenlenerek kullanıma açılmıştır. (Şekil 5) Fazla sayıda kişinin bir araya gelmesine sebep olan müsabakaların yapıldığı stadyum benzeri yapılara ise halen seyirci alınmaması bu yapıların fiziksel mesafe kuralları kapsamında tekrardan düzenlenmesinin gerekliliğini göstermektedir. Kapalı spor salonlarında her bir spor aletinin diğeri ile olan mesafesine özen gösterilmeli, bölücü elamanlardan destek alınmalı ve sslak hacim kullanımlarında özenli bir sterilizasyon sağlanmalıdır. (Şekil 6) Sonraki süreç içerisinde yaşanabilecek olası durumlar göz önüne alınarak tasarımların geliştirilmesi gerekmektedir. 


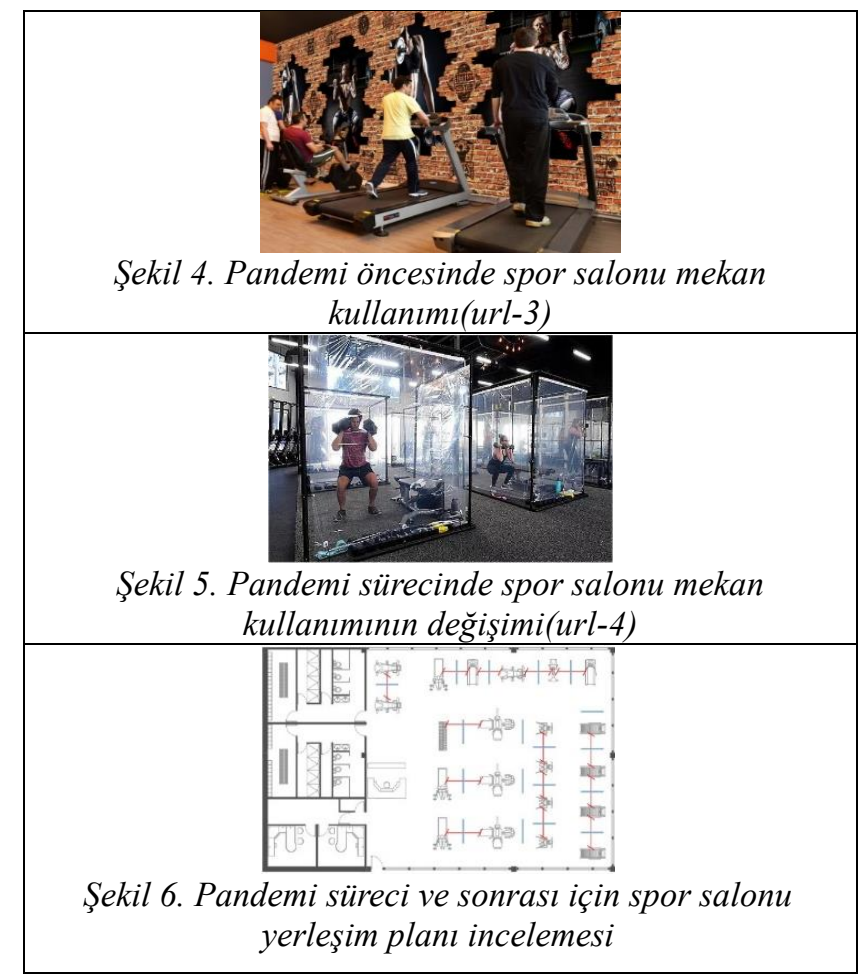

\section{Açık (Yeşil) Alanlar}

Pandemi ile birlikte hayatımıza giren mesafe kuralları kamusal alanlarda metrekareye düşen maksimum kullanıcı sayısı gibi ölçütleri daha anlamlı kılmıştır. Açık bir mekân olsa da bazı kamusal alanlar yoğun kullanımları dolayısıyla sıkışık düzende biraya gelinmesine sebep olan alanlardandır. (Şekil 7) Yaşadığımız süreç içerisinde oluşması muhtemel yoğunluğun önüne geçebilmek amacıyla yerel yönetimler öncelikli açık kamusal alanların kullanımını yasaklamış, ilerleyen zamanlarda da farklı düzenlemelere gidilerek mekanlara farklı kısıtlamalar getirilmiştir. Kentsel donatıların bir araya gelişi ve hatta tasarımları bile bu süreçten etkilenmiş, kısıtlamaların azalması ile birlikte açık ve yeşil alanlarda sosyal mesafe kurallarına uygun bir organizasyon oluşturulmaya çalışılmıştır. (Şekil 8, 9) Pandemi sonrası dönemde de kentsel ve kamuya açık mekanlarda görülmesi muhtemel olan bu fiziksel biçimleniş, kalıcı bir davranış kalıbına dönüşme potansiyeli taşımaktadır. Gelecekte yapılacak olan planlamaların bu kriterleri dikkate alarak tasarlanması gerekli görülmektedir.

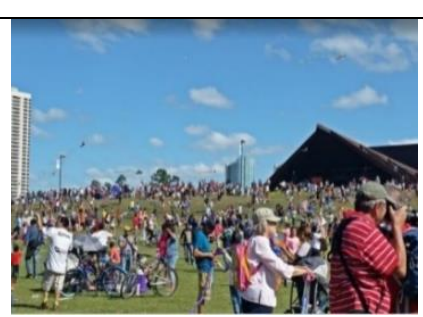

Şekil 7. Pandemi öncesi açık/yeşil alan kullanımı(url-5)

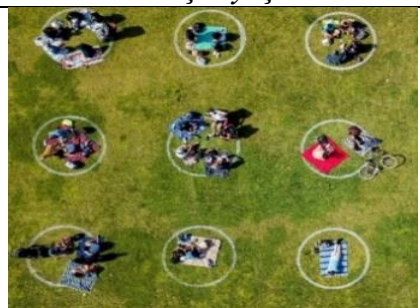

Şekil 8. Pandemi sürecinde yeşil alan mekan kullanımının değişimi(url-6)

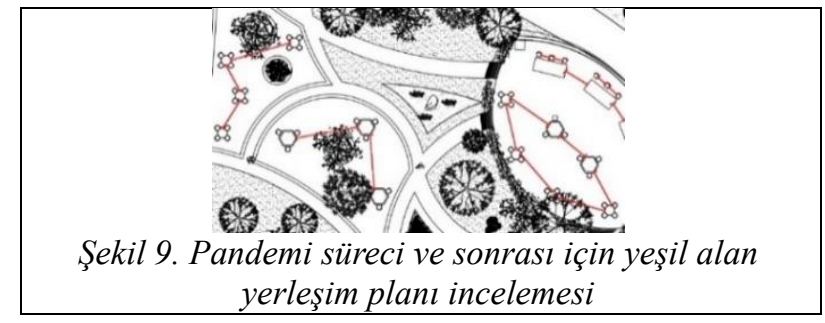

\section{Dini Yapılar}

Her toplumun sahip olduğu dini inanışların farklı olması nedeniyle farklı mekân kullanımlarının söz konusu olduğu dini yapılarda genel olarak toplu olarak ibadete olanak verecek mekânsal düzenlemeler mevcuttaki hallerine bağlı kalarak devam etmektedir. (Şekiş 10) Pandemi sürecinde bir süre kısıtlamaya gidilmesine karşın sonraki zamanlarda ibadet için belli sayıda kişinin o alanda bulunmasına izin verilerek mekanlar tekrar kullanıma açılmıştır. Halen devam eden uygulamalarda bu mekanlarda sosyal mesafe kuralları dahilinde uyarıcı yer işaretleri ile kullanıcıların fiziksel mesafelerinin, giriş ve çıkışlara kurulan dezenfeksiyon alanları ile temas edilen yüzeylerin sterilitesinin korunması amaçlanmaktadır. (Şekil 11, 12) Pandemi sürecinde uygulanan mekânsal düzenlemeler pandemi sonrası süreç için de uygulanmaya devam edilebilir ve yeni oluşturulacak tasarımlara bahsedilen mekânsal organizasyonlar entegre edilebilir.

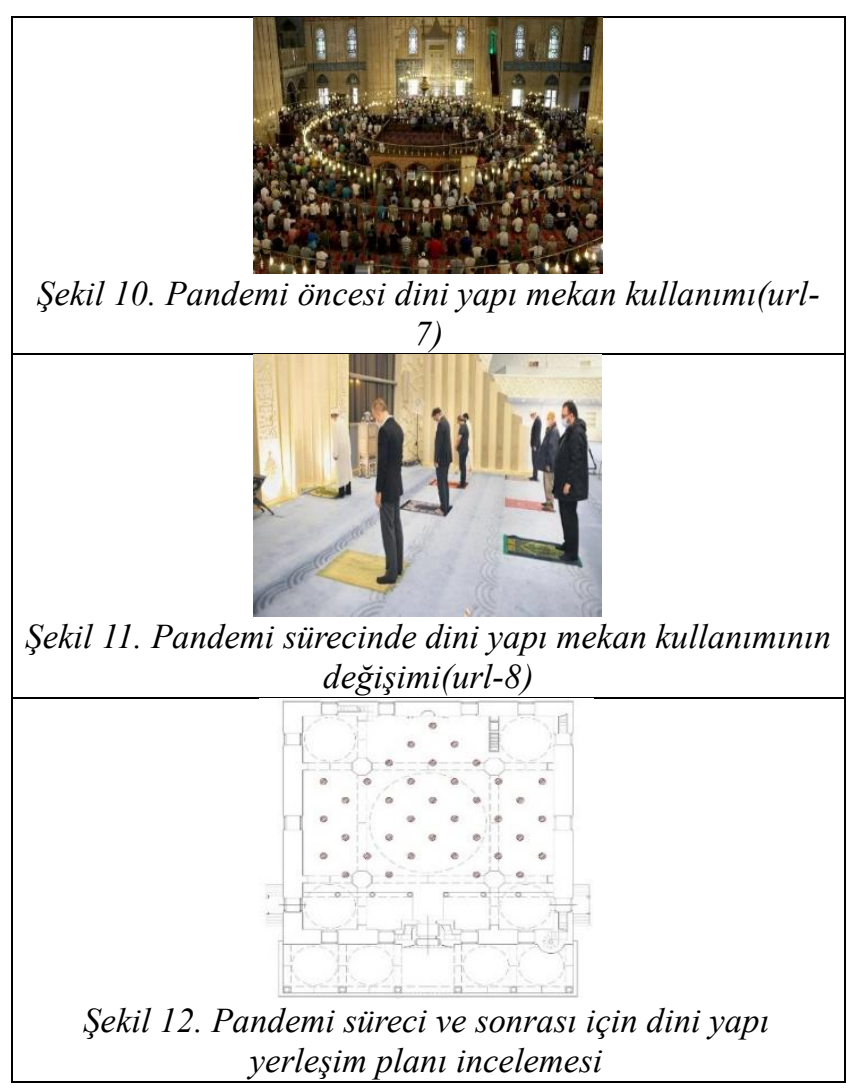

\section{Ofis/ Çalıșma Alanları}

Özellikle pandemi öncesi dönemde günümüzün büyük bir kısmını geçirdiğimiz ofis mekanları, yoğun kullanıcı potansiyeline sahip olduğu için süreç içerisinde mekânsal dönüşümün neredeyse zorunlu hale geldiği mekanlar arasında yer almıştır. (Şekil 13) Yaşanan süreç içerisinde birçok kurum ve kuruluş farklı çözüm yolları aramış; bir kısmı yoğunluğu azaltmak adına kademeli çalışma planına geçerken, bir kısmı da evden çalışma planına geçmiştir. Bahsedilen durumların haricinde evden çalışmanın yürütülemediği durumlarda mecburi hale gelen 
ortak alan kullanımlarını sınırlandırmak için ise bölücü elemanlar, farklı mekân sınırlayıcıları ve renkli uyarıcı ekipmanlarla mekânın kullanıcıları arasında gerekli fiziksel mesafenin bırakılması sağlanmaya çalışılmıştır. (Şekil 14)

Bahsedilen kapsam içerisinde çalışma masalarının birbirine olan uzaklığı ve bölücü elemanların kullanımı gibi pandemi öncesi süreçte çok dikkate alınmayan bazı ölçütler şimdilerde salgını kontrol altına alabilmek için uygulanan tedbirler arasındadır. Uygulamaya konulan tedbirlerle birlikte esnek mekân anlayışıyla planlanan mekanların sahip olduğu fonksiyonellik, pandemi sonrası süreçte de göz önünde bulundurulması gereken bir olguyu ortaya çıkarmıştır.

Pandemi sonrasını için kamusal kullanıma açık olan, çok sayıda kişinin uzun süreli olarak mekân içerisinde vakit geçirmesinin gerektiren ofis benzeri yapılarda hem çalışanların hem de ziyaretçilerin sağlı̆̆ açısından öncelikli olarak giriş çıkış alanları için mümkünse ayrı kapılar sağlanmalı oluşacak yoğunluk azaltılmalıdır. Ana sirkülasyon alanlarda yeterli genişlikte akslar bırakılarak mekân içerisinde dolaşım daha sağlıklı hale getirilmelidir. Kısa süreli kullanımda mekânın kullanıcılarının dolaşmadan işlerini halledebilmeleri için gerekli düzenleme ve sosyal mesafe kuralına uygun olarak bekleme alanlarında yeterli oturma alanları sağlanmalıdır. Çalışanların gün içerisindeki temasını en aza indirmek için yan yana masa düzeni yerine bölücü panellerle her çalışana ayrı bir kullanım alanı sağlanmalıdır. Yaşanılan pandemi süreciyle birlikte önemi herkes tarafından daha iyi anlaşılan doğal havalandırmanın mekân içerisinde sirkülasyonunun sağlanması için bölücü duvarlar havalandırmayı sekteye uğratmayacak şeklide konumlandırılmalıdır. (Şekil 15)

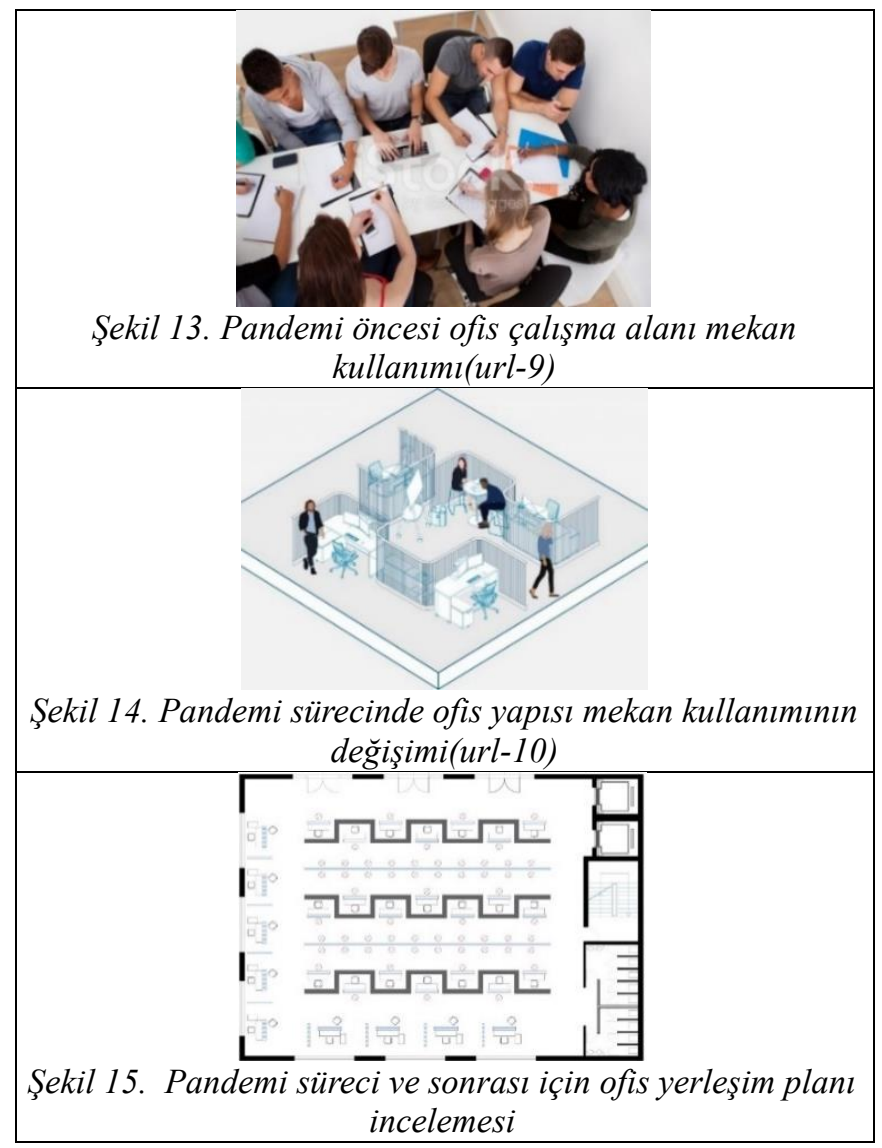

\section{Pazar Alanları}

Temel ihtiyaçlarımızı karşılayabilmek adına kullanmak durumunda kaldığımız mekanlardan biri olan semt pazarları, pandemi ile birlikte değişime uğrayan mekanlar arasında yer almıştır. (Şekil 16) Salgının başlamasıyla birlikte kullanıcıların bireysel ve sosyal izolasyonunun sağlaması amaciyla semt pazarlarında çeşitli önlemler alınmış ve uygulamaya konulmuştur. (Şekil 17) Pandemi sonrası süreç için de halen yoğun bir kullanıcı potansiyeline sahip olması beklenilen pazar yerlerinde, tezgahlar arası mesafenin belli aralıklarda tutulmasını sağlamak için mekânsal sınırlayıcı elemanlarla düzenlemeye gidilerek satıcılar ve müşteriler arasındaki temas azaltılmaya çalışılmaktadır. Mekânın kullanıcılarının pazar yeri içerisindeki temasını azaltmak içinse satılan mallar kategorilere ayırılıp farklı alanlarda gruplandırılarak kullanıcıların alan içerisindeki sirkülasyonu azaltılmaya çalışılmalıdır. (Şekil 18) Salgın süreci ve sonrasında oluşabilecek yeni risklere karşı bu mekanların dinamik sirkülasyonunun kontrol altına alınması başlıca tasarım kriterlerinden birini oluşturmalıdır.

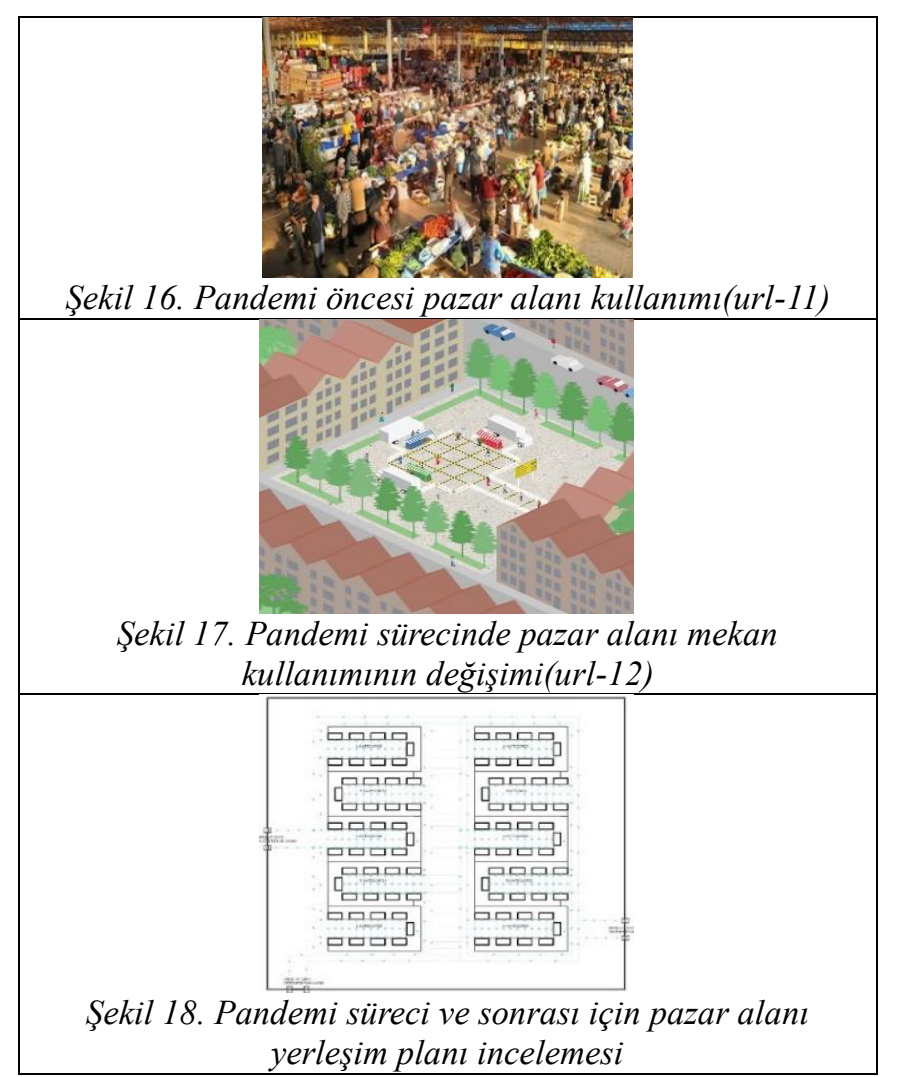

\section{Eğitim- Öğretim Yapıları}

Küresel çapta birçok kişinin etkilenmesine sebep olan salgın sebebiyle aksayan eğitim-öğretimin devamlılığını sağlayabilmek için bireylerin birbiriyle temasını en aza indirgeyecek mekân tasarımlarının oluşturulması gerekmiştir. (Şekil 19) Bunun için sınıf mevcutlarında azaltmaya gidilmesi, sınıf içerisinde teması en aza indirmek için sıraların çapraz oturma düzeninde kullanılması, ders dışında öğrencilerin temasını azaltmak amacıyla teneffüse sınıfların sırayla çıkarılması gibi uygulamalara gidilmiştir. (Şekil 20) Salgının başında öncelikli olarak eğitim-öğretime ara verilmesi sonrasında aralıklarla tekrardan eğitimin devam etmesine uğraşılması fakat salgının kontrol altına alınamaması ve olası riskler sebebiyle tekrar sürecin sonlandırılması eğitimöğretim yapılarında ciddi bir dönüşümün gerektiğini göstermektedir. $\mathrm{Bu}$ nedenle çok sayıda kişinin birbirleriyle etkileşim içinde olduğu eğitim- öğretim yapılarında özellikle sınıf içinde öğrenciler arası gerekli sosyal mesafe bırakılmalı, sınıf 
içinde ve dışında belirli aralıklarla hijyen noktaları bulunmalıdır. Mekanların fiziksel konforunu arttırabilmek için doğal havalandırmaya olanak veren tasarımlar geliştirilerek yapı içerisindeki iklimlendirmenin uygun koşullarda kalması sağlanmalıdır. (Şekil 21) Aynı zamanda yapı içerisinde ve dışında öğrencilerin sosyalleşebilmesine olanak sağlayan mekanlar oluşturularak sosyal sürdürülebilirliğin devamlılığı sağlanabilmelidir.

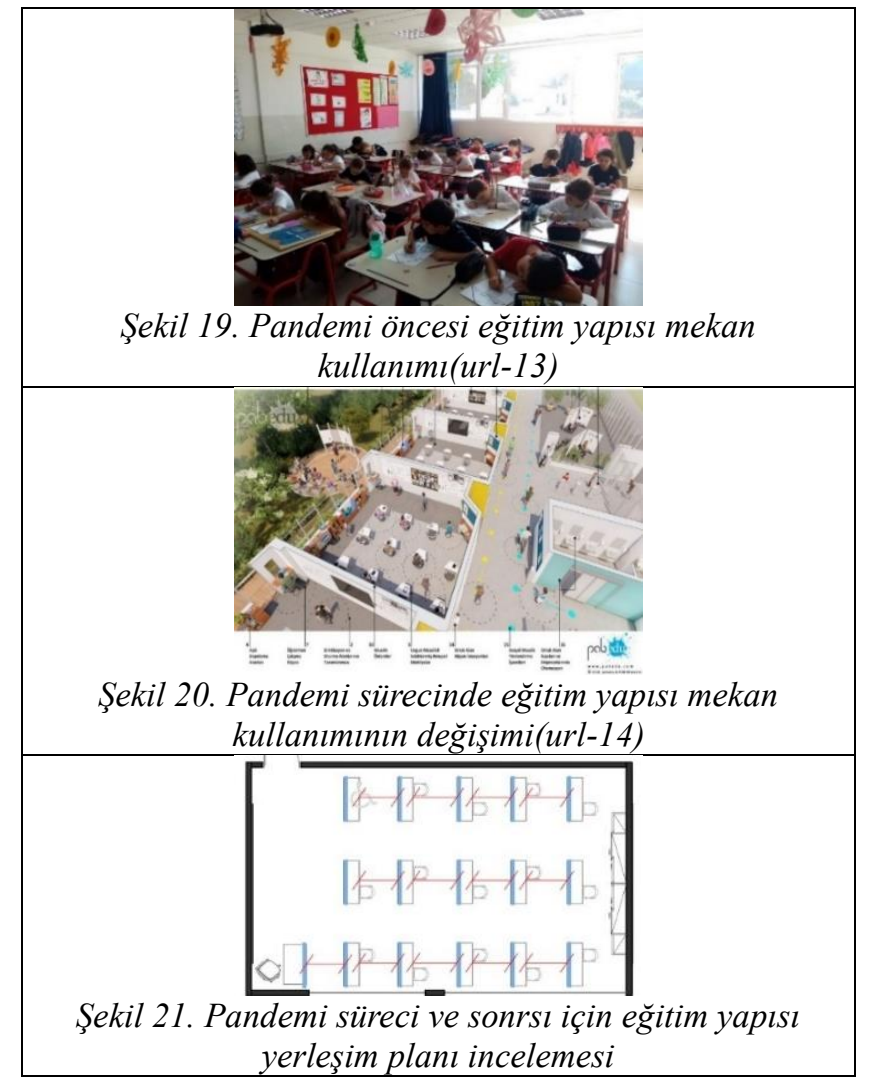

\section{Resmi Yapılar}

Sürece uyum sağlayabilmesi için değişim ve iyileştirmeye uğraması gereken yerlerden biri de resmî kurumların kullanımındaki mekanlar olmuştur. Bu mekanlar içerisinde yoğun kullanım alanlarının başında yer alan resmi kurum, hastane, banka gibi mekanlar bulunmaktadır. Salgının hem maddi hem de manevi açıdan sebep olduğu olumsuzlukları en aza indirmek için bu mekanların salgın sirası ve sonrası kullanıma uygun olarak düzenlenmesi gerekmektedir. (Şekil 22) Pandeminin başlamasıyla birlikte birbirinden bağımsız birçok kişinin kullanımına açık olan bu mekanlarda öncelikli olarak mekân içi kişi sınırlamaları getirilmiş, belli bir sayının üzerine geçilmemesine çalışılmıştır. (Şekil 23) Giriş ve çıkışlara dezenfeksiyon standantları kurularak kişilerin olası tehlikelerden ve uyarıcı işaretleriyle mekân içerisindeki sirkülasyon mekanlarında yakın temastan korunması amaçlanmıştır. Pandemi öncesinde mekân içerisinde kullanılan donatılar sosyal mesafe kurallarının uygulanmasını zorlaştırması sebebiyle süreç içerisinde ya tamamen kaldırılmış ya da bölücü sınırlayıcı elemanlar ile belli standartlara getirilmeye çalışılmıştır. Alınmaya çalışılan önlemlerin tümü mekanların esnek kullanıma olanak verecek şekilde düzenlenmesi gerektiğini göstermiştir.

Bu amaçla bahsedilen mekanların bekleme alanlarında yoğun insan temasının önüne geçebilmek için öncelikli olarak mekân kullanımını kisitlayan mobilyalar azaltılarak temiz alanlar bırakılmaya çalışılmalı, oturma yerleri arasında bölücü elemanlar kullanılarak gerekli sosyal mesafenin korunması sağlanmalıdır.
Uyarıcı yer işaretleriyle fiziksel mesafenin iç mekandaki sirkülasyon alanlarında da korunmasına özen gösterilmelidir. Ayrıca mekanların doğal havalandırmasının sağlanması açısından, pandemi öncesinde doğal havalandırma yerine çoğunlukla tercih edilen, yapay havalandırma en aza indirilmeye çalışılarak mekanların dışarıyla olan bağlantısı güçlendirilmeye çalışılabilir. (Şekil 24)

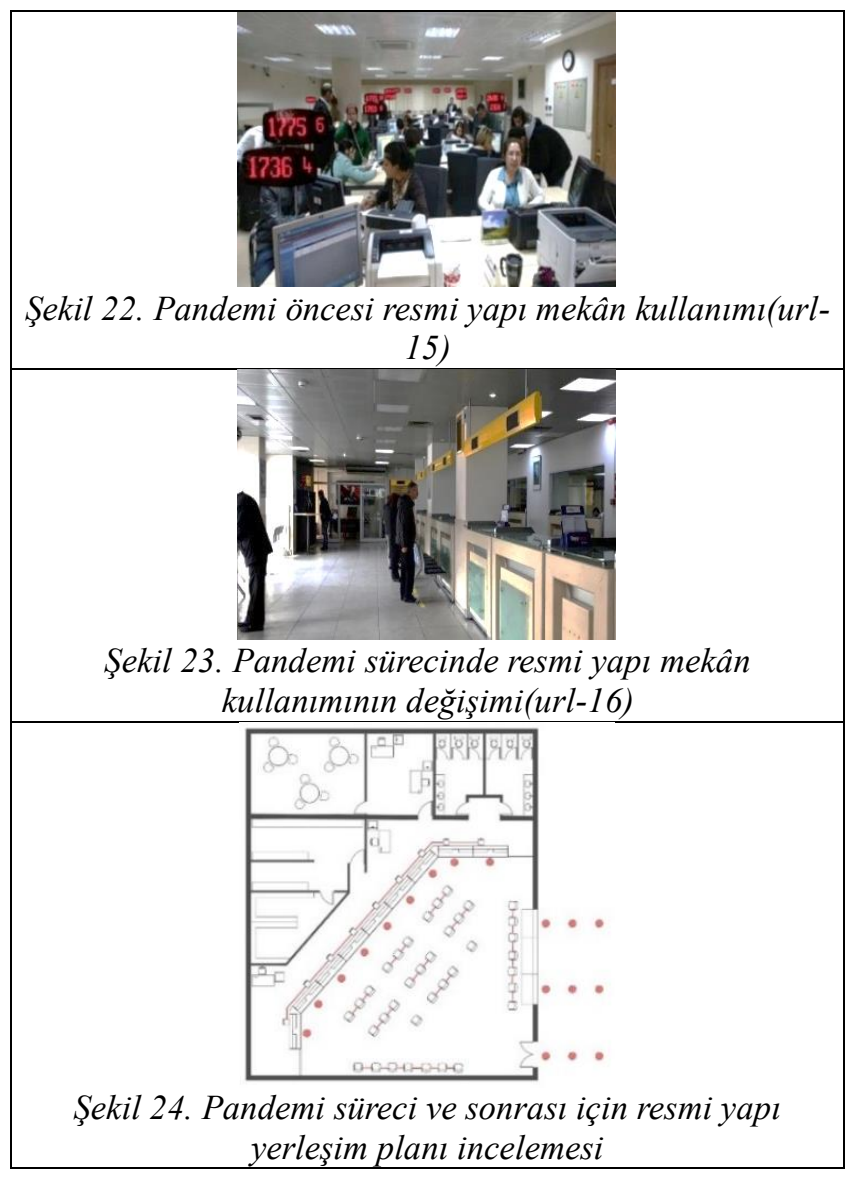

\section{Sosyo-Kültürrel Yapılar}

Tüm dünyayı her yönden etkisi altına alan salgın sebebiyle çoğu ülkede olduğu gibi ülkemizde de sanatsal ve kültürel aktiviteler askıya alınmış, salgının kontrol altına alınabilmesi ve yeni gelişen duruma karşın kullanıma açık olan mekanların standartlarının geliştirilmesi için çalışmalar yürütülmüştür. Pandemi öncesi dönemde sosyo-kültürel birçok etkinliğge ev sahipliği yapan konser ve konferans salonları yeterli şartları sağlayamadığı için (Şekil 25) pandemi sürecinde mevcut mekanlarda yapılacak etkinlikler salon kapasitesinin yarısı kullanılarak düzenlenmiştir. (Şekil 26) Pandemi sonrası süreç için bu mekanların salon kapasite ve büyüklükleri tekrar göz önüne alınarak kamusal kullanıma açık olan sinema gibi çok sayıda insanın bir araya gelmesine neden olan etkinlikler sırasında oluşabilecek olumsuzlukların önüne geçebilmek için kapalı ortamlarda bir kişinin kaplayacağı $\mathrm{m} 2$ yeniden düşünülmeli koltuklar arası mesafe ve salon büyüklüklerinde gidilecek düzenlemeler ile mekânların kullanılabilirliği sağlanmalıdır. (Şekil 27) 


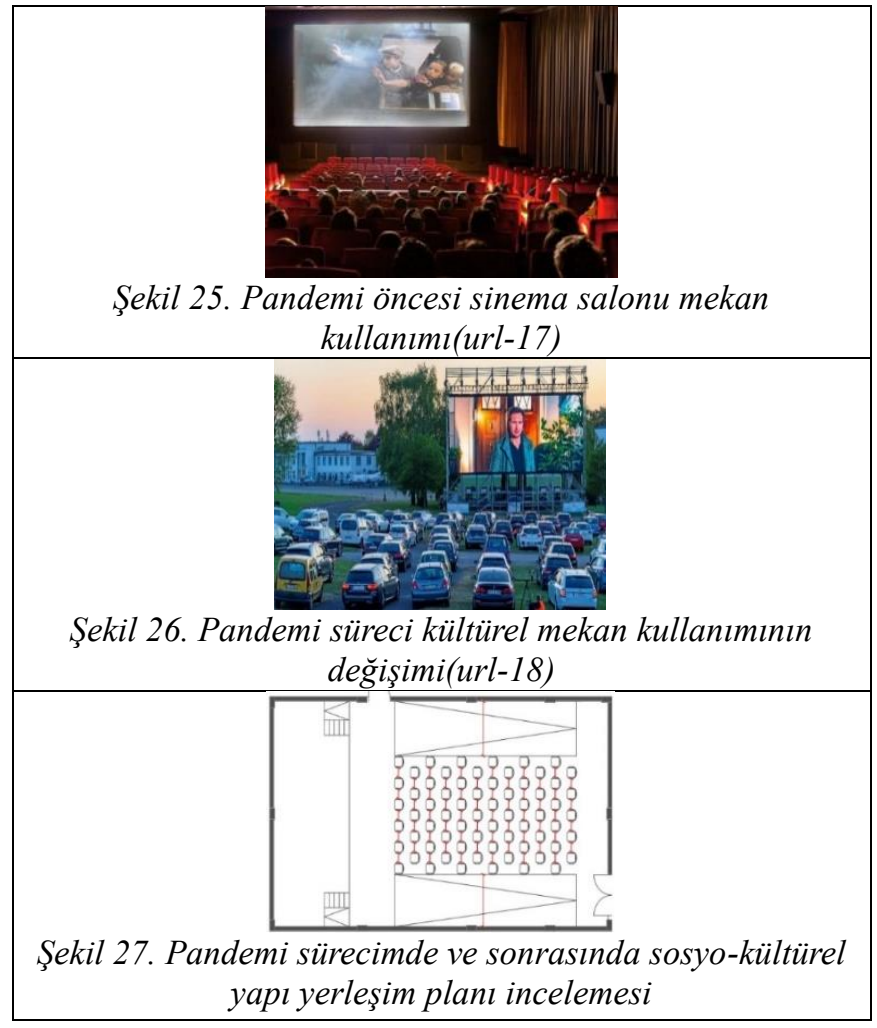

\section{Toplu Ulaşımın Sağlandığı Alanlar}

Birçok kişinin sirkülasyonun sağlandığı toplu ulaşım alanları tekrar düşünülmesi gerekilen mekanlar arasında en önemlilerindendir. Çünkü bu mekanlarda sosyal mesafe ve hijyen kurallarına uyulması mevcut kullanımları itibariyle olanaksız ve konforsuzdur. (Şekil 28) Yaşanılan bu süreçle birlikte birçok kişi pandemi öncesinde de düzeltilmesi gerekilen bu sorunun iyiden iyiye farkına varmış ve farklı kullanım modellerinin geliştirilmesinin önemi gözler önüne serilmiştir. Pandeminin başlamasıyla birlikte her gün yüzlerce kişinin kısa süreli kullanımına açık olan toplu ulaşım yerlerinin hem bekleme hem de ulaşım araçlarında uyarıcı işaretlerle kişilerin fiziksel mesafelerini korumaları için önlemler alamaya çalışılmış, her iki kullanım yeri içinde oturma yerlerinde sınırlandırmalara gidilmiştir. (Şekil 29) Başlarda özellikle şehir içi otobüs ve metro gibi çok sayıda kişinin günlük kullanımında olan toplu ulaşım mekanlarında belli bir sayının üstünde kişi araca alınmamış, iç mekânda dezenfeksiyon yerleri oluşturularak temas yerlerinin steril kalması sağlanmaya çalışılmıştır. Pandemi sonrası için bu mekanlarda ele alınan mekanlarda öncelikli olarak oturma alanlarının seyreltilerek yatayda ve düşeyde yeterli kişisel mekân tanımına uygun boşluğun bırakılması, 2'li ve 5'li koltukların azaltılması ve uzun süreli yolculuklar içinde izole bir yolculuk sağlanmaya çalışılması üzerinde durulmalıdır. (Şekil 30) Yaşanılan süreç öncesinde de kişisel mesafe sınırlarını hiçe sayan ulaşım araçları ve mekanlarının gerekli fiziksel mesafeyi sağlayacak şekle getirilmesinin gerekli olduğu düşünülmektedir.

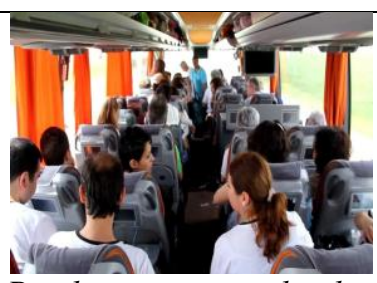

Şekil 28. Pandemi öncesi toplu ulaşım mekan kullanımı(url-19)

$e-I S S N: 2148-2683$

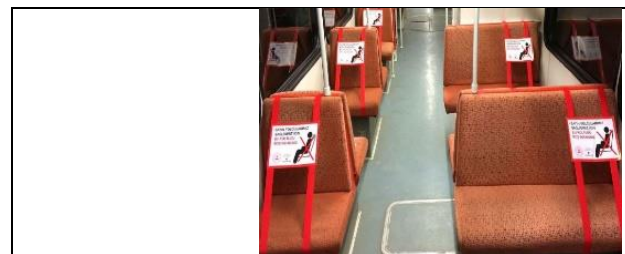

Şekil 29. Pandemi süreci toplu ulaşım mekan kullanımının değişimi(url-20)

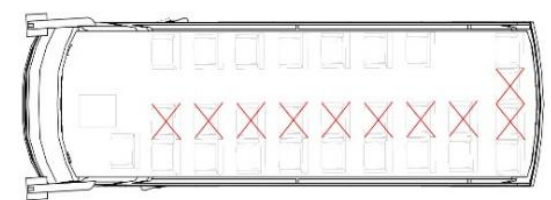

Şekil 30. Pandemi süreci toplu ulaşım yerleşim planı incelemesi

\subsection{Anket Bulguları}

Çalışma online olarak, etik kurul izni alınarak 2021 MartNisan ayları içerisinde yürütülmüştür. Anket kapsamında kat1lımcilara birinci senaryota 10, ikinci senaryota da 10 olmak üzere toplamda 20 soru yöneltilerek cevaplandırmaları istenmiştir. Anketörler yerel halkın her kesiminden seçilmiş olup, katılımcıların yaş grupları ve eğitim seviyeleri aşağıdaki tablolarda ifade edildiği gibi dağılım göstermektedir.

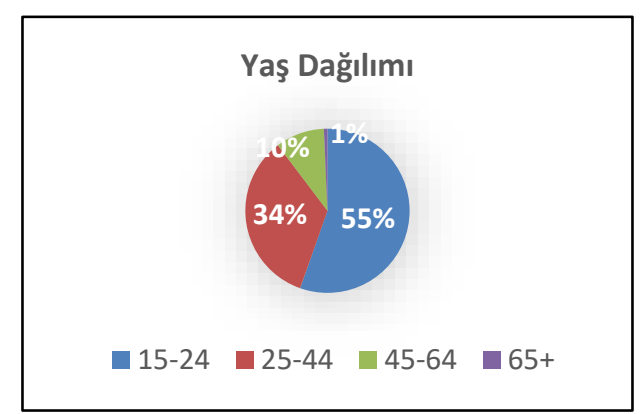

Çizelge 2. Yaş Dă̆ılımı

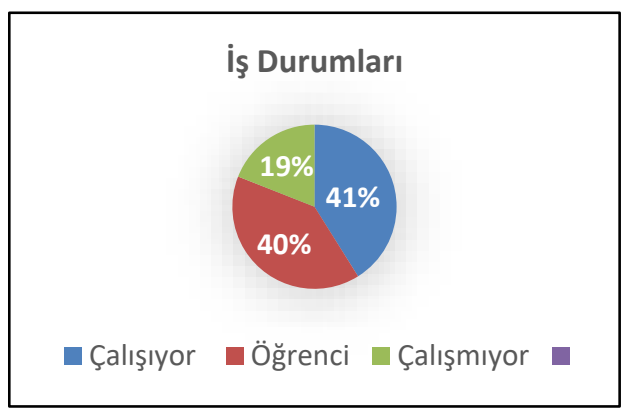

Çizelge 3. İş Durumlarl

Çizelge 2'de görüldüğü üzere \%43'ü erkek \%57'si kadın olan katılımcıların \%55,4'ü 15-24, \%34,3'ü 24-44, \%9,6's1 45-64, $\% 0,7$ 'si 65 yaş ve üzeri gruptan oluşmaktadır. Aynı şekilde çizelge 3 'ten elde edilen veriler ile katılımcıların \%40,3'ünün öğrenci, \%19,2'sinin çalışmıyor ve \%41,5'inin ise aktif olarak çalışıyor olduğu görülmektedir.

İlgili bölümde pandeminin kamusal mekân kullanımına olan etkisini ortaya koyabilmek amaciyla düzenlenen anketin güvenilirliği test edilmiş, analiz sonucunda Cronbach's Alfa değerinin $\alpha=0,703$ olarak oluştuğu görülmüştür. Cronbach Alpha değerinin 0,6'in üzerinde olması, anketin oldukça güvenilir 
olduğunu göstermektedir. (Yıldız, D. Uzunsakal E, 2018) Çalışma için daha sonra örnekleme ait demografik özellikler belirlenmiş, anket sonucunda elde edilen veriler ile demografik özellikler arasındaki ilişkilerin sorgulandığı hipotez testi sonuçları iki farklı senaryo dahilinde ele alınmıştır.

Çalışmada ortaya çıkan veriler SPSS 20 programı kullanılarak analiz edilmiştir. Örneklemin salgının iki farklı olasılığına göre ortaya çıkan değerlerini çalışıp çalışmama durumu ve yaşa göre karşıllaştırmak amaciyla Paired Sample Ttest, ANOVA ve Kruskal-Wallis Analizi uygulanmıştır. Araştırma dahilinde pandeminin tamamen sona erdiği Senaryo 1 ve daha da kötü bir hal aldığ 1 Senaryo 2 için sorulara verilmiş olan cevapların arasındaki ilişkiyi ortaya koyabilmek için Paired Sample T test uygulanmış elde edilen sayısal verilerden öncelikli olarak " $t, \mathrm{df}$ ve Sig. değerleri ele alınmış, pandeminin bitmesi ya da devam etmesiyle mekan kullanımı arasındaki ilişki ortaya konulmaya çalışılmıştır. Belirlenen örneklem dahilinde Senaryo 1 ve Senaryo 2 için sorulara verilen cevaplar incelenen senaryo içerisinde ele alınarak, yaş ve çalışma durumlarına göre verilen cevap arasında anlamlı bir ilişki olup olmadığını öğrenmek amacıyla Anova Analizi (Varyans Analizi) yapılmış ve sig. değerine bakılmıştır. Her iki inceleme için anlamlı bir sonucun çıkmadığı durumlarda Kruskal-Wallis Testi uygulanarak verilen cevaplar ile sorulara cevap verenlerin yaş ve çalışma durumları arasındaki ilişki tekrar kontrol edilmiştir. Bu bağlamda aşağıda seçilen sorular üzerinden yapılan analiz sonuçlarına ve değerlendirmelerine yer verilmiştir.

Anket çalışmasında yer alan 'Ofis arkadaşınızla aynı masayı kullanır misiniz?' (1.soru) sorusuna verilen cevaplar ve SPSS Programı'nda yer alan Paired Samples Test (Bağımlı Örneklem TTesti) sonucunda; sig. 0,22 değeri ile senaryo 1 ve senaryo 2 kategorisindeki yanıtlar arasında anlamlı bir fark bulunmuştur. Pandeminin sona erdiği ve uzun zamandır küresel ölçekte bir vakaya rastlanılmadığı bilinen senaryo 1 ile pandeminin sona ermediği ve artarak devam ettiği senaryo 2 durumu arasında bu sorudaki davranışların \%.27'lík bir fark ile arttığı görülmektedir. Yani birinci senaryota \%47,3 olan 'hayır' yanıtının ikinci senaryota daha ciddi bir boyuta \%74,3'e ulaştığı görülmektedir.

Anket çalışmasında yer alan 'Bulunacağınız mekanda aradığınız kriterler arasında 'kişisel izolasyon', 'sosyal mesafe' gibi kavramlar bulunur mu?' (10.soru) sorusuna verilen cevaplar ve uygulanan Paired Samples Test sonucunda; sig. 0,00 değeri ile senaryo 1 ve senaryo 2 kategorisindeki yanıtlar arasında anlaml bir fark bulunmuştur. Senaryo 1 ile Senaryo 2 durumu arasında bu sorudaki davranışların \%16,8'lik bir fark ile arttığı görülmektedir. Yani birinci senaryota \%72,3 ile ciddi bir düzeyde olan 'evet' yanıtının ikinci senaryota \%89,1 ile çok daha ciddi boyutlara ulaştığı görülmektedir. Bu anlamda her iki olasılığın sonucu olarak pandeminin mekanlar üzerinde bir değişiklik bırakacağ yargısına ulaşılmıştır ve anketörlerin gidecekleri mekanları, fiziksel mesafeye kurullarına uygun olup olmamasına göre tercih etmesini etkilediği yargısı çıkarılmıştır (Çizelge 4).
Çizelge 4. Paired Samples T-Test Sonuçları

\begin{tabular}{l|l|l|l}
\hline & $t$ & $d f$ & $\begin{array}{l}\text { Sig. } \\
\left(\begin{array}{l}2 \\
\text { tailed } \\
)\end{array}\right.\end{array}$ \\
\hline $\begin{array}{l}\text { Pair 1 } \\
\text { Senaryolsoru1-- } \\
\text { Senaryo2soru1 }\end{array}$ & $-2,323$ & 134 &, 022 \\
\hline $\begin{array}{l}\text { Pair 2 } \\
\text { Senaryo1soru10-- } \\
\text { Senaryo2soru10 }\end{array}$ & 5,178 & 134 &, 000 \\
\hline
\end{tabular}

Anket çalışmasında yer alan senaryo 2 kategorisinde 'Pandemi öncesi dönemde (tercih ediyorsanız eğer) olduğu gibi semt pazarlarını tercih eder misiniz?' (8.soru) sorusuna verilen cevaplar ve Anova Analizi sonucunda ulaşılan sig. 0,11 değeri ile iş durumu arasında anlamlı bir fark bulunmuştur. Öğrenci ve çalışan grubun bu soruya verdiği hayır çoğunluklu yanıtlar doğrultusunda çalışmayan kesimin pandeminin sona ermediği ve devam edeceği senaryo 2 durumunda bile semt pazarlarını tercih edeceği yargısına ulaşılmıştır. $\mathrm{Bu}$ anlamda semt pazarları gibi kalabalık mekanlarda sağlık önlemleri üzerinde daha çok durulmalıdır (Çizelge 5, Çizelge 6).

Çizelge 5. Senaryo 2 Soru 8-Anova Analizi Sonuçları

\begin{tabular}{l|l|l|l}
\hline Senaryo2-Soru8 & $\boldsymbol{d f}$ & $\boldsymbol{F}$ & Sig. \\
\hline $\begin{array}{l}\text { Gruplar arası } \\
\text { (ilişkisiz gruplar) }\end{array}$ & 2 & 4,652 &, 011 \\
\cline { 1 - 2 } $\begin{array}{l}\text { Gruplar içi (ilişkili } \\
\text { gruplar) }\end{array}$ & 132 & & \\
\cline { 1 - 2 } Toplam & & & \\
\hline
\end{tabular}

Çizelge 6. Senaryo 2 Soru 8 Cevap Tablosu

\begin{tabular}{l|l|l|l}
\hline İş Durumu & Evet & Hayır & Kararsızım \\
\hline Çalışıyor & 22 & 24 & 6 \\
\hline Ö̆grenci & 12 & 27 & 12 \\
\hline Çalışmıyor & 15 & 9 & 2 \\
\hline
\end{tabular}

Anket çalışmasında yer alan senaryo 1 kategorisinde 'Kalabalık organizasyonlara katılır misınız?' sorusuna verilen cevaplar ve SPSS Programı'nda yer alan Anova Analizi sonucunda; sig. 0,12 değeri ile iş durumu arasında anlamlı bir fark bulunmuştur. Pandeminin sona erdiği ve uzun zamandır küresel ölçekte bir vakaya rastlanılmadığı bilinen Senaryo 1'de öğrenci ve çalışan kitlenin, çalışmayan kitleye göre kalabalık organizasyonlara daha fazla katılacağı sonucuna ulaşılmıştır (Çizelge 7, Çizelge 8). 
Çizelge 7. Senaryo 1 Soru 9-Anova Analizi Sonuçları

\begin{tabular}{|c|c|c|c|}
\hline Senaryo1-Soru9 & $d f$ & $F$ & Sig. \\
\hline $\begin{array}{l}\text { Gruplar arasl } \\
\text { (ilişkisiz gruplar) }\end{array}$ & \multirow{3}{*}{$\begin{array}{l}2 \\
164 \\
166\end{array}$} & \multirow[t]{3}{*}{4,580} & \multirow[t]{3}{*}{,012 } \\
\hline $\begin{array}{l}\text { Gruplar içi } \\
\text { (ilişkili gruplar) }\end{array}$ & & & \\
\hline Toplam & & & \\
\hline
\end{tabular}

Çizelge 8. Senaryo 1 Soru 9- Cevap Tablosu

\begin{tabular}{l|l|l|l}
\hline Yaş & Evet & Hayır & Kararsızım \\
\hline 15-24 yaş & 63 & 6 & 7 \\
\hline $\mathbf{2 5 - 4 4}$ & 36 & 7 & 2 \\
\hline $\mathbf{4 5 - 6 4}$ & 9 & 5 & - \\
\hline
\end{tabular}

Anket çalışmasında yer alan senaryo 1 kategorisinde 'Eğitim kurumlarında, restoranlarda masaların birbirine olan uzaklığına ya da sinema, tiyatro gibi kamusal kullanıma açık mekanlardaki koltukların birbirine olan mesafelerine dikkat eder misiniz?' sorusuna verilen cevaplar ve SPSS Programı'nda yer alan Kruskal-Wallis Analizi sonucunda ulaşılan sig. 0,020 değerinden yaş grubunun kamusal kullanıma açık mekanlardaki koltukların birbirine olan mesafelerine dikkat etme durumunu değiştirdiği yargısına ulaşılmıştır. Belirli yaş grubundaki kişilerin kamusal kullanıma açık mekanlarda bulunan oturma düzeninde uyulması gereken fiziksel mesafeye özen gösterdiği, yaş arttıkça bu olguya olan dikkatin azaldığı anlaşılmaktadır (Çizelge 9, Çizelge 10)

Çizelge 9. Senaryo 1 Soru 5- Kruskal-Wallis Analizi Sonuçları

\begin{tabular}{l|l}
\hline Senaryo1-Soru5 & \\
\hline$d f$ & 2 \\
\hline Asymp. Sig. &, 020 \\
\hline
\end{tabular}

Çizelge 10. Senaryo 1 Soru 5- Cevap Tablosu

\begin{tabular}{l|l|l|l}
\hline Yaş & Evet & Hayır & Kararsızım \\
\hline $\mathbf{1 5 - 2 4}$ & 72 & 13 & 8 \\
\hline $\mathbf{2 5 - 4 4}$ & 48 & 9 & - \\
\hline $\mathbf{4 5 - 6 4}$ & 11 & 6 & - \\
\hline
\end{tabular}

Anket çalışmasında yer alan senaryo 2 kategorisinde 'Pandemi süreci içerisinde alınan bazı mekânsal kısıtlamaların sonrası içinde uygulanmasının gerekli olduğunu düşür müsünüz?' sorusuna verilen cevaplar ve SPSS Programı'nda yer alan Kruskal-Wallis Analizi sonucunda ulaşılan sig. 0,023 değeri ile yaş olgusu arasında anlamlı bir fark bulunmuştur. Pandeminin hiç bitmeyeceğinin bilindiği bir senaryoda mekânsal kısıtlamaların uygulanmaya devam edilmesinin yaş arttıkça gereksiz olduğunun düşünüldüğü anlaşılmaktadır (Çizelge 11, Çizelge 12).

Çizelge 11. Senaryo 2 Soru 3-Kruskal-Wallis Analizi Sonuçları

\begin{tabular}{l|l}
\hline Senaryo2-Soru3 & \\
\hline$d f$ & 2 \\
\hline Asymp. Sig. &, 023 \\
\hline
\end{tabular}

Çizelge 12. Senaryo 2 Soru 3-Cevap Tablosu

\begin{tabular}{l|l|l|l}
\hline İş Durumu & Evet & Hayır & Kararsızım \\
\hline Çalışıyor & 25 & 35 & 11 \\
\hline Öğrenci & 23 & 32 & 17 \\
\hline Çalışmıyor & 3 & 26 & 3 \\
\hline
\end{tabular}

\section{Sonuç}

İçinde bulunduğumuz dünya, yaşadığımız çağ hızlı bir değişim geçirerek her yeni gün farklı bir ihtiyaç kalıbının ortaya çıkmasına sebep olmaktadır. Günümüzün en büyük ve birincil sorunu haline gelen pandemi de hiç durmadan yaşanan değişimin daha radikal bir şekilde gerçekleşmesine sebep olmuştur. Günlük rutinlerin, yeme içme alışkanlıklarının, sosyalleşmek için kullandığımız mekanların, eğitim ve iş hayatlarımızın kökünden değişmesine sebep olan bu farklılaşma, yirmi birinci yüzyılın insanlarını da ihtiyaçlarını karşılamak için dönüştürmeye, günümüze uyumlu hale getirmeye zorlamaktadır. Pandemi süreci içerisinde bu dönüşümden en çok etkilenen şeylerin başında hiç şüphesiz yaşamımızın temelini oluşturan mekanlar yer almaktadır. Mekansal kullanımlarımızı olabildiğine değiştiren bu süreç artık kişisel ve toplumsal olarak kalıcı birtakım değişikliklerin gerektiğini göstermiş hemen hemen tüm yapılı çevrede standartları değiştirmiştir.

Yapılan çalışma sonucu pandemi süreci içerisinde oluşan mekân değişimleri örnekler ile ortaya konularak kamusal mekanlarda görülen kullanım alışkanlıklarının değişimi incelenmiştir. Çalışmada yerel halk ile yapılan iki farklı senaryo şeklinde SPSS programı kullanılarak irdelenen anketten elde edilen verilere göre katılımcıların çoğunluğu pandemi sürecinde getirilen kısıtlamaların bu süreç sona erse bile devam etmesi gerektiğini belirtmesi mekanların tasarımında kalıcı bir değişikliğe gidilmesi gerektiğini doğrulamıştır. Makalenin ikinci bölümünde ise mekanların pandemi öncesi, pandemi sırası ve pandemi sonrası muhtemel kullanımları ve anket sorularına verilen cevaplar, karşılaştırmalı olarak incelenmiştir.

Anket çalışmasında katılımcılara yöneltilen senaryo 1 soru 1 senaryo 2 soru 1 senaryo 1 soru 10 senaryo 2 soru 10'dan (sig. 0,022 - sig. 0,000) elde edilen verilere uygulanan Paired Samples T-Test Analizi, senaryo 2 soru 8'den (sig. 0,011) elde edilen verilere uygulanan Anova analizi, senaryo 1 soru 9'dan (sig. 0,012) elde edilen verilere uygulanan Anova Analizi, senaryo 1 
soru 5'ten (sig. 0,020) elde edilen verilere uygulanan KruskalWallis Analizi, senaryo 2 soru 3'ten (sig. 0,023) elde edilen verilere uygulanan Kruskal-Wallis Analizi sonucunda kamusal mekanların kullanım açısından eski şekli ile sürdürülebilirliğinin kalmadığı güncel duruma adapte mekanların yeniden tasarlanması gerektiği ortaya konulmuştur. Yapılan incelemeler ve kullanılan analiz yöntemi 1şığında elde edilen bulgular yaklaşık iki yıldır dünya gündeminin meşgul eden pandemi ve sonuçları ile alakalı önümüzdeki dönemlerde daha çok bilimsel çalışma yapılması gerektiğinin de bir göstergesidir.

\section{Kaynakça}

Altan, İ. (1993). Mimarlıkta Mekan Kavramı (2005 Yayınları, C. 19). Geliş tarihi gönderen https://dergipark.org.tr/tr/pub/iupcd/118010

Asar, H. (2013). Mimari Mekân Okumasında Algisal Deneyim Analizinin Bir Yöntem Yardımıla Irdelenmesi (Yüksek Lisans Tezi). Eskişehir Osmangazi Üniversitesi.

Avar, A. (2009). Lefebvre'in Üçlü -Algılanan, Tasarlanan, Yaşanan Mekân- Diyalektiği. TMMOB Mimarlar Odasl Ankara Şubesi Dosya Dergisi, (17), 7-16.

Bilgin, N. (1990). Fiziksel mekândan insani ya da insanlı mekâna. Mimarlık Dergisi, 28(3), 62-65.

Duman, S. (2018). Mekan Algisı ve Gestalt Kuramı. Program adı: Karadeniz Teknik Üniversitesi Fen Bilimleri Enstitüsü. Karadeniz Teknik Üniversitesi Fen Bilimleri Enstitüsü. Geliş tarihi gönderen https://www.academia.edu/37991444/MEKAN_ALGISI_V E_GESTALT_KURAMI

Erdönmez, E., \& Çelik, F. (2016). Kentsel Mekanda Kamusal Alan İlişkileri. TÜBA-KED Türkiye Bilimler Akademisi Kültür Envanteri Dergisi, (14), 145-163.

Lefebvre, H. (1991). The Production of Space (S. D Nicholson, Çev.). Oxford.

Solak, S. S. G. (2017). Mekân-Kimlik Etkileşimi: Kavramsal ve Kuramsal Bir Bakış Space-Identity Interaction: a Conceptual and Theoretical Overview. MANAS Sosyal Araştırmalar Dergisi, 6(1), 13-37.

Tekeli İ. (2000). Dünyanın Salgınlar ve Kentler Sarmalında Geldiği Nokta; Covid-19 İlhan Tekeli. Efil Yayın Grubu, 126.

URL-1 https://www.dogahasereilaclama.com/cafe-ve-restorantilaclama/ (A.T. 07.12.2020)

URL-2 https://addo.com.tr/covid-19/ (A.T. 10.12.2020)

URL-3 https://www.duvaronline.com/Spor-Salonu-FitnessDuvar-Kagidi (A.T. 07.12.2020)

URL-4 https://onedio.com/haber/her-uyesi-icin-kapsul-seklindeozel-alan-olusturarak-sosyal-mesafe-kuralinin-hakkiniveren-spor-salonu-909111 (A. T. 21.12.2020)

URL-5 https://pxhere.com/tr/photo/738129 (A.T. 08.12.2020)

URL-6 http://www.naturadergi.com/anasayfa/post-pandemikmimarlik/ (A.T. 10.12.2020)
URL-7 https://www.aa.com.tr/tr/turkiye/uzmanlar-camilerinyeniden-toplu-ibadete-acilmasini-olumlu-karsiliyor/1856001 (A.T. 10.12.2020)

URL-8 https://www.sabah.com.tr/dunya/2020/05/17/sosyalmesafeli-namaz (A. T. 21.12.2020)

URL-9 https://www.freeimages.com/tr/premium/universitystudents-doing-group-study-888713 (A.T. 10.12.2020)

URL-10 https://www.dezeen.com/2020/06/26/perkins-and-willmeena-krenek-offices-post-coronavirus-pandemic/(A.T. $\underline{07.12 .2020)}$

URL-11 https://www.hendekgundem.com/guncel/hendekpazaryeri-acik-h15210.html (A.T. 11.12.2020)

URL-12 https://www.archpaper.com/2020/04/speculativecoronavirus-design-concepts/ (A.T. 08.12.2020)

URL-13 https://www.pabedu.com/yeni-normalde-okul-yapilari (A.T. 08.12.2020)

URL-14 https://pbs.twimg.com/media/EGbm5O0XoAQHlro.jpg (A.T. 08.12.2020)

URL-15 https://www.bursahayat.com.tr/haber/nobetci-nufusmudurlugu-uygulamasi-205407.html (A.T. 08.12.2020)

URL-16 https://www.aa.com.tr/tr/turkiye/pttden-sosyal-mesafeuyarisi/1788310 (A.T. 08.12.2020)

URL-17 https://in.pinterest.com/pin/480618591474776424/ (A.T.13.12.2020)

URL-18 https://www.sozcu.com.tr/2020/dunya/corona-birefsaneyi-yeniden-canlandirdi-arabali-sinemalar-geri-dondu5786606/amp/ (A.T.14.12.2020)

URL-19 https://duslerdengercege.com/2010/09/12/sehirlerarasiotobus-yolculuklari/ (A.T. 08.12.2020)

URL-20 https://rayhaber.com/2020/03/gaziantepte-otobusve-tramvaylara-sosyal-mesafe-seridi-cekildi/ (A.T.21.12.2020) 